Tarih Kültür ve Sanat Araştırmaları Dergisi

Revue des Recherches en Histoire Culture et Art

مجلة البحوث التاريخية و الثقافية و الفنية
Vol. 7, No. 5, December 2018

Copyright (C) Karabuk University

http://kutaksam.karabuk.edu.tr

\title{
DOI: 10.7596/taksad.v7i5.1911
}

Citation: Vasil'eva, A. (2018). Recreation of the "Olonkho Style" in Russian in Translations of the Epic Works of P. A. Oyunsky. Journal of History Culture and Art Research, 7(5), 180-188. doi:http://dx.doi.org/10.7596/taksad.v7i5.1911

\section{Recreation of the "Olonkho Style" in Russian in Translations of the Epic Works of P. A. Oyunsky}

\author{
Akulina Aleksandrovna Vasil'eva ${ }^{1}$
}

\begin{abstract}
The highest form of the folklore of every nation is the epic which expressive means are unique in relation to the artistic word of other nations and are common for all the oral and literary artistic creativity of the nation which wrote the epic. Therefore, the article's comparative analysis of the translation equivalents of the linguistic means which form the elevated "olonkho style" in Russian is conducted on the basis of the works of one of the founders of Yakut literature, Platon Oyunsky, and has the goal of identifying ways of transferring the "olonkho style", i.e. transferring the Yakut language features to the translation not only through culture-specific vocabulary but by other means as well. In result, the means of the Russian language able to adequately convey the "olonkho style" in Russian are identified. First of all, these are the tools that distinguish elevated style in the Russian language itself - archaisms and high style vocabulary. Translators choose words with the lowest level of national features from the wide range of this vocabulary, i.e. those words that are applicable to translate elevated style texts of any other language. When conveying the "olonkho style", the morphological methods of composition and synonyms and antonyms combination in paired words are actively used. These word-building patterns are specific for the Russian language, but when translated from Yakut into Russian, the national features are conveyed by the unusual combinations of words for the Russian language. The most distinctive feature of the "olonkho style" - and the most difficult in translation - is the conveyance of the rhythmic pattern of the epic narration. This can be done by imitating syntactic parallelisms based on vowel harmony and synonymity, by constructing equal-word and parisyllabic repeating syntactic constructions that do not necessarily reproduce the number of parallelisms in the original. Thus, when translated into Russian, the "olonkho style" is recreated not only due to the exoticness of the source material but also due to the exploitation of word-building and clause-forming potential of the target language.
\end{abstract}

Keywords: Epic works, Epic style, Olonkho style, Folk tradition, Literary translation, Alliteration, Syntactic parallelism, Culture-specific vocabulary.

\footnotetext{
${ }^{1}$ Candidate of Philological Sciences, Associate Professor, Department of Sakha Stylistics, Institute of Languages and Cultures of the Peoples of the North-East of the Russian Federation, North-Eastern Federal University, Yakutsk, Russia. E-mail: vaaperevod@mail.ru
} 


\section{Introduction}

Platon Alekseevich Oyunsky is the founder of Yakut Soviet literature, a reformer of the Yakut versification, a linguist, and a statesman. He united all his capacities to achieve the only ultimate goal - to preserve the distinctive cultural heritage of his native people, to integrate it into the culture of a large country, so his compatriots would not lose themselves as a people in the era of great change.

The literary works of Platon Oyunsky are rich with folklore. The poetic style of this folklore has been polished over many centuries and reflects not only the folk aesthetics but also the way of thinking and the mentality of the Yakut people. From early childhood, Platon Oyunsky absorbed the poetry and wisdom of Yakut folklore and became a famous olonkhosut, a person who bears and creates folklore. The classical education that Platon Oyunsky received in Yakutsk, as well as the influence of revolutionary ideology (which was also expressed in his literary activities), contributed to the fact that in his literary works he consciously drew together original Yakut folklore and Russian classical literature, primarily poetry. He gained influence and earned nationwide recognition through his oratory and poetic talent when he spoke at rallies and meetings. In the spring of 1917, at the request of his senior colleagues, he translated into his native language revolutionary songs intended for sing-alongs at mass events.

Platon Oyunsky worked in many genres of literature - poetry, prose, drama, and all his works are in their style and aesthetics close to folklore for the following reasons: 1 ) he is a creator of folklore, a poet, a "yryasyt"; 2) most of those who read and listened his works was brought up on this folk aesthetics and better perceived this form of the narration of new ideas; 3 ) The goal of Platon Oyunsky as a national leader and the chief visionary of the new development of his native people's culture was the preservation of national identity. That is why he revised the images of his native folklore and gave them a new sound corresponding to his time.

For Yakut culture, the works of Platon Oyunsky are a kind of bridge for the transition to another culture, to new concepts of the world and the place of a person in it. The works of Platon Oyunsky prepared the Yakuts of that time to eagerly accept the new ideology and culture of the new social system. The reason for Platon Oyunsky to work so diligently on the quality of his works is that the art of declamation was the most accessible and powerful mean of ideological influence in those days. Being the works of a thinker, they hide a lot of diverse information in themselves, they are mysterious and multifaceted and are of great interest to many readers of different abilities and interests. From the many aspects of Platon Oyunsky's works, this article concentrates on the unique artistic features. The works' reproduction of the original Yakut folklore traditions is the dominant feature of translation into Russian which recreates the "olonkho style" or "Yakut spirit".

\section{Methodology}

It is folklore that is the source of the uniqueness of national literature. Epic works are intended to show the heroic past of the people. This past is idealized by the narrators of folk tales, who intentionally distance it from the present and rise it above daily routine. That is why not only vocabulary but also syntax form elevated style of narration, which is called the "olonkho style" in relation to Yakut works.

The difficulty of translating the works of Platon Oyunsky lies also in their versatility. Firstly, they inevitably affect the mythology of the Yakut people because they are based on legends and traditions. These works are intertextual and abound with numerous allusions, which most often either left out of the translation or explained in comments, inevitably cluttering up the translation. Secondly, these works are philosophical. According to the researchers, they allegorically express Platon Oyunsky's views on totalitarian power and his thoughts on the fate of his own people, about people and power, about the person in power, etc. 
(Sidorov, 2017). These works bear the imprint of the era in which they were written, even though they have a timeless folklore form. At the same time, such works broach philosophical, eternal questions, which makes them timeless, non-national, and classical. As a result, they receive a contemporary edge not only in literary translations but also in intersemiotic (theater plays, etc.). This is where the true potential of the thinker's works lies. In addition, these works require responsible translators with thoughtful and careful attitude to the original. Translators also need to be creative in dealing with translation problems because they appeal to the collective memory of the people, operate with model characters and figures of speech.

In this article, observations of translational methods and comparison of original texts with translations reveal the units that form the "olonkho style" in Russian, at the level of vocabulary, morphology (wordbuilding) and syntax.

\section{Translations of Platon Oyunsky's Epic Works into Russian}

Platon Oyunsky has several epic works: the novels "Kudangsa Velikii" ("Kudangsa the Great") (1929), "Keerekeen" (1936), the stories "Aleksandr Makedonskii" ("Alexander the Great") (1935), "Solomon Mudryi" ("Solomon the Wise") (1935), the plays "Krasnyi Shaman" ("The Red Shaman") (1917-1925), "Tuyaaryma Kuo Svetlolitsaia" ("Tuyaaryma Kuo Fair-Faced") (1928), the olonkho "Niurgun Bootur Stremitel'nyi" ("Nyurgun Bootur the Swift") (1932). These works can be divided into two groups: a) prosaic, with greater influence of the author; these are deep philosophical works based on Yakut legends (here we also include the olonkho-toyuk "Krasnyi Shaman" because the author's influence here is stronger than in the works of the second group); b) poetic, with the more accurate reproduction of the content of original folklore text on all levels: the olonkho "Nyurgun Bootur Stremitel'nyi", the drama "Tuyaaryma Kuo Svetlolitsaya". All these works of Platon Oyunsky are united by the folkloristic nature not only of the denotative content but also of the style.

From these works, the novel "Kudangsa Velikii" (1991), the story "Aleksandr Velikii" (2002), the dramatic works "Krasnyi Shaman" (1930, 1963), "Tuyaaryma Kuo Svetloltsaya" (1978), and the olonkho "Niurgun Bootur Stremitel'nyi" were translated into Russian.

The main artistic features of Yakut folklore are: a) alliteration based on the natural law of the Yakut language's vowel harmony; b) syntactic parallelisms built on alliterated parallel constructions; c) a variety of unique figurative and expressive means (paired words, repetitions, ready-made poetic formulas, phraseological units, paroemias, comparisons, epithets, metaphors, etc.) which characterize the style of Yakut folklore. These means form the genres of Yakut folklore mainly through the differentiation in the rhythm of the narration, which depends on the subject and purpose of the text, and different combinations. Specifically, the major genres of Yakut folklore, which include the epic olonkho, legends, and tales of yore, are distinguished (except, of course, heroic content) by a special rhythm: long sentences and tirades (the longest units of an epic verse) with complex heterogeneous definitions, parallel repetitions, inversion, etc. These artistic means, being developed over many centuries by generations of Yakut singers and narrators, fully meet the artistic and poetic aesthetics of the people, and form the "face" of the entire Yakut poetic culture. In modern Yakut literature, we can find the epic style rhythm in major works, which also based on folklore, of such widely recognized writers as Ivan Gogolev, Vasilii Dalan, and others.

As a distinctive expression of the epic style of Yakut folklore, this particular epic narration rhythm must be somehow conveyed to other languages when translated. Naturally, this task is impossible because the translation of a work of art (i.e. the conversion of the work to another cultural environment) inevitably leads to a collision with a different artistic and poetic aesthetics. Therefore, the task of a translator is to select such linguistic and artistic means of the translating language which resemble the epic style of the original and are close or equal in terms of having an impact on the recipient of the receiving culture. 
As noted by S. Danilov and G. Okorokov, the work "Kysyl oiuun" - "Krasnyi Shaman" [The Red Shaman] (A.F. Boyarov and P.N. Chernykh-Yakutsky, 1930; Valentin Korchagin, 1963), written in 1917-1925, is "the first work of Platon Oyunsky on the subject of folklore inspired by the heroics of olonkho and associated with folk mythology, cult and ritual" (Danilov \& Okorokov, 1978, p.27). The plot is based on two legends: about the struggle of the shaman Dobun with the powerful Orosin clan, and about the leader of the Kudangsa clan, who married his daughter to Ulutuiar, the demon of Upper World, in order to save his people from the diseases sent by the country of this demon. In this work the folk mythology and the writer's fiction are closely intertwined. In addition, the plot and the problematics of the work are two-dimensional: using the material of ancient legends, the novelist drew parallels with his historical period, transforming the legendary characters into symbols of revolutionary and Soviet reality and saying the ideas of his time through them. This work is included in the repertoire of the Sakha Drama Theater. In November 1967 the opera "Krasnyi Shaman" premiered. The libretto was written by D.K. Sivtsev-Suorun Omolloon, the music was written by the composer G.I. Litinsky.

The Drama "Tunalgannaakh N'uurdaakh Tuyaaryma Kuo" (Noruot Olonkhotuttan) (1928) - "Tuyaaryma Kuo Svetlitsaya" [Tuyaaryma Kuo the Fair-Faced] (Vladimir Derzhavin, 1978). The dramatic poem was written for a stage performance and as a test before writing a more extensive epic work - "Niurgun Bootur Stremitel'nyi". It was a search of a form of literary processing of the olonkho, a folklore work with the potential of dramatic art. This dramatic work for a stage production differs in form (with remarks, with actions and phenomena, etc.) from the olonkho performed verbally. There are no descriptions here, but the characters are outlined in accordance with the oral olonkho, the heroic style is fully preserved. Moreover, the play differs from the olonkho in its dynamics. The first Yakut opera (libretto by D.K. Sivtsev Suorun Omollon, music by M.N. Zhirkov and G.I. Litinsky) was inspired by this play. That is, we see here an example of an intralingual intersemiotic translation. It is interesting to learn what from the olonkho was saved, and what was changed, modified, or omitted: the core of the epic text remains unchanged while the parts insignificant (according to the author) for the olonkho style are transformed.

The Novel "Uluu Kudangsa" (1929) - "Kudangsa the Great" (Albina Borisova, 1991). Comparing the original legend about Kudangsa, written by P.V. Sleptsov, and the story of Platon Oyunsky, V.T. Petrov noted that "the language of the story is close to the language of olonkho, the tendency to verse the speech, which increases the significance of the popular word, is tangible." (Petrov, 1974, p.211). In Yakut folklore and literature, the tendency to verse the prose speech is a sign of the highest mastery of the author of a work. Usually, such works are recognized by critics as pinnacles of literary creativity. Platon Oyunsky's olonkho and epic prose, and the free translation of M.Yu. Lermontov's poem "The Demon" made by A.E. Kulakovsky, one of the founders of Yakut literature, in 1908 may be included here.

V.T. Petrov gives numerous examples of Platon Oyunsky's adoption and enhancement of folk formulas in describing the nature, emotions of the characters, and the dialogues in the novel "Kudangsa Velikii". Such an approach has shaped the unique style of this work, which corresponds to the author's intention and the work's subject and content. Therefore, the translation should be as such of the heroic epic olonkho.

The Olonkho "D'uluruiar N'urgun Bootur" (1932) - "Nyurgun Bootur Stremitel'nyi" [Nyurgun Bootur the Swift] (Vladimir Derzhavin, 1975). With the claim that "the olonkho "Niurgun Bootur Stremitel'nyi" is not a self-recording of the olonkhosut Oyunsky but a highly artistic work of the writer and poet Oyunsky", the researchers P.N. Dmitriev and S.D. Mukhopleva, following V.A. Semenov (1980, pp.161-164), distinguish in this work three innovations of Platon Oyunsky as a creative mind: 1) a poetic breakdown of the epic text; 2) the introduction of "lyrical digressions", unusual for oral olonkho; 3) the introduction of parisyllabic and equal-word lines in adjacent verses (Dmitriev \& Mukhopleva, 2004, p.74-75). In other words, the poet Platon Oyunsky worked on the form of Yakut folklore poetry, and this is precisely what makes his olonkho 
different from all the others. Thus, these innovations represent the uniqueness of the style of Oyunsky's olonkho, which most likely have been reflected in the translation into Russian.

\section{Recreation of the "olonkho style" in Translations of Works of Platon Oyunsky into Russian}

As it is known, the aforementioned works by Platon Oyunsky had a difficult fate: they received strong, politically charged criticism from contemporaries, were banned and forgotten, and then returned to the people, and were read anew. They directly affected the writer's fate, and still influence the assessment of the life and work of this great son of the Yakut people. Over the years, more and more of new facets of Platon Oyunsky's thoughts about person and society, about the strength of the spirit, and the values of life are revealed.

The first translation of the epic works of Platon Oyunsky is the translation of "Krasnyi Shaman". It is known that its first translation into Russian was made in 1930, within the lifetime of Platon Oyunsky. He even wrote a preface to the publication and praised the translators for the accuracy of the translation: "After reviewing the text of the Russian translation of my poem "Kysyl Oiuun" from folk mythology, I am very satisfied with the translation. Such a translation was possible only because it was made by those two persons who know folk mythology and folk art well, and who are proficient in the Yakut language and Yakut poetry as much as the author is... Of course, no translation can claim to accurately convey the connotations of each word. What is beautiful and rich in one language cannot always be beautiful and sonorous in another. Beauty and richness are generated by the laws of each language, completely different from each other. The translation of "Kysyl Oiuun" conveys all the content in almost exactly the same parlance as in which the poem has been written. Translators should be congratulated on a successful translation ..." (Oyunsky, 1975, p.368). Maxim Gorky, the head of the writers' organization of the entire Soviet Union, was introduced to the interlinear translation of this poem and concluded that the work had high ideological and artistic qualities. His conclusion put an end to the negative criticism of the work started in Yakutia (Mordinov, 1985, p.39).

In 1963, after the rehabilitation of the name of Platon Oyunsky, "Krasnyi Shaman", one of the most significant works of all Yakut literature, was translated again by Valentin Korchagin. This translation is distinguished, first of all, by a poetic form, in which dactylic size with pair rhyme prevails. In other words, the external form of translation is fully consistent with the aesthetics of the receiving culture, and the national distinctness of the original is demonstrated through culture-specific vocabulary. Inaccuracies in the content and the translation of the key points have probably alleviated the perception of the work, but in Soviet times, researchers pointed out these inaccuracies (Semenov, 1980, pp.89, 98).

In 1975 the first edition of the translation into Russian of Platon Oyunsky's olonkho "Niurgun Bootur Stremitel'nyi" by Vladimir Vasilyevich Derzhavin, a seasoned translator of the epic of different nations, was published. The translation into Russian of this olonkho became an image product that broadcast Yakut culture for the whole world, a cultural event which gave impetus to the growth of the self-consciousness of the Yakut people. This translation contributed to the introduction of the Yakut heroic epic to the number of masterpieces of the intangible heritage of mankind by UNESCO in 2005, thereby activating the government support of the preservation of the Yakut epic and the development of the cultural identity of the Yakut people. In 1983 S.V. Mikhalkov, the secretary of the board of the Writers' Union of the USSR, who wrote the afterword to the translation of $\mathrm{V}$. Derzhavin, said about the significance and quality of this translation the following words: "Having recreated the Yakut heroic epic in a perfect and harmonious form, Platon Oyunsky accomplished a feat similar to the feat of Lennrot, the discoverer of the Karelian folk runes. As you know, on this basis he created the world famous "Kalevala" (Mikhalkov, 1985, p.22).

According to I.V. Pukhov, the translation of the olonkho "Niurgun Bootur Stremitel'nyi" into Russian by V.V. Derzhavin "faithfully and artistically justifies the spirit and the imagery of the olonkho and its storylines. 
While preserving the style of the original, it creates a parallel system that recreates the original poetic system" (Pukhov, 1982, p.422). The lexical features of this translation are in the skillful combination of archaisms and other vocabulary of the elevated style of the Russian language, which has a national tinge of lesser extent (dlan' [palm], zenitsa [pupil of the eye], vervie [rope], vertliuga [swivel], vladyka [overlord], ispolin [giant], polymia [flame]...), and of Yakut ethnographic culture-specific elements (aiyy, abaasy, ad'arai, chechir, sele...) that characterize Yakut life and mythology.

One of the signs of the artistic style in the Yakut language is syntactic parallelism based primarily on the law of vowel harmony, associated with synonyms and antonyms, as well as with pair words that extend the meaning of a particular lexical unit. Traditional folklore parallelisms are widely used in the epic works of Platon Oyunsky. Translators do not always translate them literally, but they always demonstrate this feature of Yakut folklore in Russian translations. Specifically, V. Derzhavin does not always strictly adhere to the number of parallelisms, but some of them are always reproduced in his translation.

Sensing the beauty of repetitions and "harmoniously weaving a verbal pattern" like an olonkhosut, Vladimir Derzhavin very often uses word combinations unusual for the Russian reader: volshebno-chernyi tuman [magically black fog], nenasytno-buinye nebesa [ravenously wild skies], gulko-shirokaia vys' [hollowly wide height], stremitel'no-gladkie belye nebesa [swiftly smooth white skies], etc. In addition, we observe in translation a composition that "hints" at the unique beauty of the imaginative speech of the original: deviatiizluchistyi put' [nine-bended path], trekhluchistye glaza [triple-radiant eyes], chetyrekhraskatistyi grom [four times thunder peal], etc.

Morphological method of composition is common in Russian too (for example, nouns parokhod [steamer], parovoz [steam locomotive], benzovoz [fuel truck], etc, as well as the notorious Soviet Newspeak). However, V. Derzhavin, skillfully using this word-building model, creates new words, mostly adjectives, which, due to their novelty, are perceived by the reader as something else, not entirely Russian.

The syntactic features of this translation lie in the fact that extensive tirades specific for Platon Oyunsky's olonkho are divided by the translator into two or more large parts. This contributes to a better perception of the epic by a Russian-speaking reader who has been brought up in a somewhat different poetic tradition. In this case, alliteration disappears, replaced by the special rhythm of the white verse, and in some places by rhyme. In this regard, some researchers tend to define this translation as an "adapted poetic translation of the olonkho" (Petrova, 2010, p.70).

Almost simultaneously with this translation, Vladimir Derzhavin translated the dramatic work "Tuyaaryma Kuo Svetlolitsaya". When translating this text into Russian, Vladimir Derzhavin rather strictly follows the text of the original, adhering to the same translation strategy as in the translation of the olonkho. The translation of the contents of the characters' songs is accurate. In terms of volume they vary - sometimes repeats and parallelisms are reduced, and sometimes there are serious conversions. In addition, the increase in the volume of chants happens due to the explanations and additions introduced by the translator, for example: "... Alamai manan kummut Alta d'irimniir tesiinitten, Argasyttan tararan uoskeebit Akhtar aiyym aimaga, Alban aappyt ald'anan; Kulum-chgaan kummut Kuler-tyrym byatyttan, Kokhsutten tartaran uoskeebit Kostor kunum aimaga, Urduk aappyt ald'anan, Utuo surakhpyt suurallan, - ..." (Oyunsky, 1992, 240) into "Liudi, prishedshie v mir Zemnoi, S shest'iu povod'iami za spinoi, Skruchennymi iz solnechnykh luchei, Tuchami ne omrachennykh luchei, Chto zh nashi imia omracheno, Kakoiu tuchei zatmilos' ono! Ei vy, solntsem rozhdennye bogatyri S zolotymi zastezhkami za spinoi! ["... People who came to the world of the Earth, With six reins behind their backs, Twisted from the sun's rays, Rays unshaded by clouds, Well our name is shaded, What cloud has eclipsed it! Hey you, sun born warriors With golden clasps behind your backs!..."] (Oyunsky, 1978, p.160). As can be seen, the translator did not reproduce syntactic parallelism, which expresses the concept of "liudi Sredinnoi zemli [people of the Middle Land]", but limited 
himself to repeating the epithet "s povod'iami za spinoi, s zastezhkami za spinoi [with reins behind their back, with clasps behind their backs]".

Remarks of Platon Oyunsky are also very poetic. For example, the remark to the third event of the first act consists of three sentences composed of four paired parallelisms, one pair of which is a phraseological unit: "Sakha Saaryn toion togus uol dogusuollanan, Sabyia Baai khotun agys kyys aryallanan, urasattan takhsannar, togus serge turbut, aragas chechir ann'yllybyt togoy sele ortotugar olbokhtorgo olorollor. D'on ere buollallar, kien kogustere kyaraabyt, usun sanaalara tatyaryibyt. Aiyy bukhatyyrdara, uraankhai tuiguttara, sanaalara tusen, tuokh da sanata soukh ogonn'ordookh emekhsinne sugurus ere gynallar ..." (Oyunsky, 1992, p.240). These syntactic parallelisms, although considered to be prose, are phonetically and rhythmically organized and subordinated to vowel harmony, thereby delighting a Yakut person's ears with a musical, poetic sound. The translator does not try to preserve a poetic, rhythmic style of these pieces. For this translation, it is more important to convey the meaning of a remark as of a link organizing the stage action. Specifically, the mentioned remark is translated as follows: "Vykhodiat iz urasy Sakha Saaryn Toion and Sabyia Baai khotun. Toiona soprovozhdaiut deviat' parnei, a khotun - vosem' devushek. Toion I khotun sadiatshia na otdel'nye podstilki iz medvezh'ikh shkur, razostlannykh posredine shirokogo sele, gde vodruzheno deviat' konoviazei i votknut zheltyi chechir. Toion i khotun udrucheny. Ikh shirokie spiny suzilis' ikh dlinnye mysli ukorotilis'. Bogatyri aiyy, luchshie iz urankhaitsev, tozhe priunyli. Oni molcha otveshivaiut im nizkii poklon" (Oyunsky, 1978, p.160) [The Sakha Saaryn Toion and Sabyia Baai Khotun come out of the urasa. Toion is accompanied by nine lads, and the khotun by eight maidens. Toion and khotun sit down on separate beddings of bear pelts, spread out in the middle of a wide sele, where nine horse tethering-posts are erected and a yellow chechir is planted. Toion and khotun are dejected. Their broad backs narrowed, their long thoughts shortened. The bogatyrs of aiyy, the best of the Urankhais, are also depressed. They silently bow dpwn before them]". In this translation, only one parallelism is reproduced - in the literal translation of the idiom "ikh shirokie spiny suzilis' ikh dlinnye mysli ukorotilis' [their broad backs narrowed, their long thoughts shortened]".

The Novel "Uluu Kudangsa" (1929) - "Kudangsa Velikii" [Kudangsa the Great] (Al'bina Borisova, 1991). In the 1990s, a cultural renaissance of the Yakut people started, when the people who survived the Soviet era turned to their roots and discovered anew the classical works written by the founding fathers of literature. At this time, a translation into Russian of the novel "Kudangsa Velikii" appeared.

In contrast to the previous translations, this translation was made without an interlineary by a professional translator Al'bina Borisova, a native speaker of the Yakut language and bearer of Yakut culture. That is why she keenly perceives the linguistic and philosophical features of the work of Platon Oyunsky. Her work was evaluated by the researcher A.N. Myreeva as follows: "The work of Oyunsky, due to the richness of its content and the complexity of its style, posed special tasks for the translator. Only a deep knowledge of the original language and literary mastery allowed to transmit all that constitutes the essence of national expressiveness: the atmosphere and spirit of the work, the author's way of thinking, the distinctness of style... Translator A. Borisova was able to subtly and reverently convey the unique atmosphere of the work, inspired by folk legends, to preserve the originality of the author's style, its lyricism. The story's turn of phrase has not lost its orotundity. Good knowledge of two languages - Russian and Yakut - became the basis of creative success. The translation is as close as possible to the text of the original, and in this case, in our opinion, this is the surest way" (Myreeva, 1996).

If we consider the syntactic pattern of the prose narration of the Russian translation of the novel "Kudangsa Velikii", we will find a rhythm that is very close to the original, despite the often used method of explanatory translation of set epic formulas: "Pochitaiushchii sebia liudskogo rodu-plemeni, imeiushchii povod'ia za spinoi, iz solnechnogo roda, imeiushchii oblik chelovecheskii, bednyi, siryi sakha v te dalekie-davnie vremena i podumat' ne mog, chto nebo i zemlia, vse vidimoe i nevidimoe na etom svete sotvoreno lish' za shest' 
dnei. Ni snom, ni dukhom ne vedal on o tom, chto svershiv grekh, popadet $v$ ad, svershiv dobro, vosnesetsia $v$ rai. Kol' pregreshenia-prostupki vozrastut, to vzyshchut ne tol'ko s menia, no i s otpryska moego, a ne budet potomstva, to ne vyderzhit zemlia telo moe, ne sovladaet shaman s dukhom moim, prizrakom stav, izmuchu-izvedu liudei - zemliakov svoikh, tak dumal Sakha i zhil tikho, bezropotno, Nem kak ryba, glukh kak kamen'... [Thinking himself as of human clan-tribe, having reins behind his back, from a solar clan, having a human appearance, a poor, deserted Sakha in those old-ancient times, could not have thought that heaven and earth, everything visible and invisible in this world was created only in six days. Not in the very least did he know that after having committed a sin, he would go to hell, by doing good, he would ascend to heaven. If sins-wrongdoings increase, they will go after not only me, but also my son, and if there will be no offspring, my land will not withstand my body, the shaman will not overpower with my spirit, and after becoming a phantom, I will torment-exhaust my people-countrymen - Sakha thought and lived quietly and meekly. Mute as a fish, deaf as a stone ...] (Oyunsky, 2002, p.53). This is an excerpt from the prologue, where the author describes the time and place of his story, using the olonkho artistic techniques - adopting and creatively reworking set epic formula. Thus, he makes it clear to the reader that: firstly, the storyline relates to the ancient, pre-Christian, period of the history of the Yakut people, and secondly, something heroic, legendary, mythical, beyond the scope of simple mortal will be described in the work. This excerpt is given in Yakut as follows: "Argasyttan tesiinneekh aiyy aimagynan aagynaachchy, kokhsutten tesiinneekh kun uusunan koruneechchi icheen etteekh, inninen sireideekh, iegeier ikki atakhtaakh, buor kuttaakh boron Sakha ochchotoogu urukku d'yllarga sir-khallaan, kostor-kostubet butun aan doidu alta khonukka aiyllybyta buoluo dien ad'as sanaabat ebit. Aiyyny onoron aakka tusuom dien, uchugeii onoron yyraiga kotoum dien bitiger bittemmet, tuuluger tusebet ebit. Burui-seme ulaattagyna, aiyy-khara elbeetegine beiebitten, onu aasan bederbitten iestiekhtere, otton ogo-uruu suokh buollagyna, beiebitten toloru iesteebetekhterine, eppin-khaammyn sir iiem tuppakka, kuppun-surbun d'abynna oiuun kotokhpokko, sibien buolan bar d'ommun khara d'aidyam buollaga dien balyktaagar kelegeidik, symyyttaagar buteidik syld'ar buolar ebit

..." (Oyunsky, 2002, p.7). Translator Al'bina Borisova coped with the task of conveying the work's magnificent style and spirit with the capabilities of the Russian language. All the methods of transmission of the Yakut epic style mentioned above are used in the translation - vocabulary typical for elevated, solemn style (starets [elder], vzor [gaze], dostochtimyi [venerable], blagodatnyi [gracious], vosslavit' [glorify], vozdat' [repay], etc.), culture-specific elements (arangas, Odun Khaan, Chyngys Khaan, D'ylga Toion, bieres tebii, khabylyk, etc.), linguistic calques - many paired synonyms (pregreshenia-prostupki [sinswrongdoings], dalekie-davnie vremena [old-ancient times], izmuchit'-izvesti [to torment-exhaust], etc.), composition (svetlolikie (devy) [fair-faced (maidens)], vos'mistoronnii (mir) [eight-sided (world)]), and rhythmicity through parallelisms, inversion and construction of complex syntactic constructions, which are not typical for the Russian language.

Thus, it can be said that the "olonkho style" in Russian is formed by a skillful combination of lexical means (culture-specific elements, archaisms, elevated style), linguistic calques (composition, combination of synonyms and antonyms into unusual pair words). These lexical and grammatical means are used by the translator as part of an unusually complex syntax with parallel structures and tirades.

\section{Conclusion}

As a phenomenon of culture and literary text, works of Platon Oyunsky, which have a folk basis and written by a thinker, carry the strength and spirit of folk poetry, the wisdom achieved through suffering, and the author's own thoughts. Therefore, their best translations into Russian and other languages must have the same effect. The closer external form of translation is to the original (but at the same time suits to the aesthetic tastes of the readers), the higher is quality of a translation, and the greater are the skills of a 
translator. The exoticism of the source material leads to the fact that in the translations of Yakut literature and folklore into Russian (the "third literature") a completely tangible style is formed.

For many decades of the practice of folklore's artistic and scientific translation, methods and techniques of the Yakut-Russian translation have developed, set compatibilities of folk formulas, epic descriptions, model olonkho pieces have been formed. Such well-known translations of Platon Oyunsky's works as the olonkho "Niurgun Bootur Stremitel'nyi" and "Kudangsa Velikii" are acknowledged examples of literary translation and the gold standard for translators of Yakut folklore and literature.

\section{References}

Danilov, S. P. \& Okorokov, G. G. (1978). The poetry of struggle and creation. P. A. Oyunsky Poems. Moscow: Sovetskii pisatel', 5-34.

Dmitriev, P. N. \& Mukhopleva, S. D. (2004). Oyunsky and folklore. P. A. Oyunsky: myths and reality. Yakutsk: Sakhapoligrafizdat, 71-78.

Mikhalkov, S. V. (1985). Oyunsky among us. The Word about Platon Oyunsky. Ed. G. S. Syromiatnikov. Yakutsk: Yakutskoe knizhnoe izdatel'stvo, 21-23.

Mordinov, N. E. (1985). Our living contemporary. The Word about Platon Oyunsky. Ed. G. S. Syromiatnikov. Yakutsk: Yakutskoe knizhnoe izdatel'stvo, 32-40.

Myreeva, A. N. (1996) Great spirit and keen mind. Reflections on the translation of "Kudangsa Velikii". Republic of Sakha, 1996, No.7 (28362).

Oyunsky, P. A. (1975). Selected Works. 2 vol. Stories, novels, recollections, articles, speeches. Vol. 2. Yakutsk: Sakha sirineegi kingie.

Oyunsky, P. A. (1992). Selected Works: Poems, translations, dramatic poems. Yakutsk: Sakha Respublicatyn natsional'nai kingie izd-vota.

Oyunsky, P. A. (2002). Kudangsa the Great, Alexander the Great. Russian translation by A. A. BorisovaSleptsova. Yakutsk: Bichik.

Oyunsky, P. A. (1978). Poems. Moscow: Sovetskii pisatel'.

Petrov, V. T. (1974). Sounding word of folk. Founder of Yakut Soviet literature (on the 80th anniversary of the birth of P. A. Oyunsky). Yakutsk: Kn. izd-vo, 209-214.

Petrova, T. I. (2010). Typology of the translation of the Yakut epic olonkho into Russian. Yakutsk: Izdatel'skopoligraficheskii kompleks SVFU.

Pukhov, I. V. (1982). Olonkho - the ancient epic of the Yakuts. Nyurgun Bootur the Swift. The Yakut heroic epic. Translation from Yakut by V. Derzhavin. Yakutsk: lakutskoe kn. izd-vo, 411-422.

Semenov, V. A. (1980). The works of P. A. Oyunsky and the formation of socialist realism in Yakut Soviet literature. Novosibirsk: Nauka.

Sidorov, O. G. (2017). Platon Oinsky. The flaming stone Sata. Yakutsk: Bichik. 